\title{
PENDUGAAN STRUKTUR BAWAH PERMUKAN DAERAH PROSPEK PANAS BUMI DI DESA PENCONG KECAMATAN BIRINGBULU, GOWA DENGAN MENGGUNAKAN METODE MAGNETIK
}

\author{
${ }^{1)}$ Muspayanti, ${ }^{2}$ Pariabti Palloan, ${ }^{3)}$ Nasrul Ihsan \\ Universitas Negeri Makassar \\ Kampus UNM Parangtambung Jln. Daeng Tata Raya, Makassar, 90224 \\ 1)e-mail : muspamuspi2394@gmail.com
}

\begin{abstract}
Abstrak. Tulisan ini merupakan hasil tentang Struktur Bawah Permukaan daerah Panas Bumi dengan menggunakan Metode Magnetik di Desa Pencong Kecamatan Biringbulu Gowa. Penelitian ini bertujuan untuk mengetahui karakteristik anomali magnet dan struktur bawah permukaan daerah air panas Pencong. Data medan magnet total diperoleh dengan menggunakan Proton Procession Magnetometer (PPM). Hasil pengolahan data menunjukkan bahwa area panas bumi di Desa Pencong Kabupaten Gowa Sulawasi Selatan memiliki nilai anomali magnetik beragam mulai dengan -1600 nT sampai dengan $1800 \mathrm{nT}$ dan menunjukkan bahwa daerah tersebut terdapat patahan (terobosan). Selain itu ditemukan bahwa di daerah panas bumi Pencong terdapat 3 perlapisan batuan yaitu clay cap (lempung dan tuff) sebagai tempat keluarnya air panas, zona reservoir terdiri dari batuan breksi, batuan basal lapuk atau shale (serpihan) diduga sebagai batuan fluida yang terpanaskan oleh batuan pemanas, heat source terdiri dari batuan basal dan batuan andesit terubah.
\end{abstract}

Kata kunci : Metode Magnetik, Panas Bumi, Anomali Magnetik, Struktur Bawah Permukaan.

\begin{abstract}
This is the result of Subsurface Structures Geothermal area using Magnetic Method in Pencong, Biringbulu, Gowa. This study aims to determine the characteristics of the magnetic anomaly and subsurface structure of the Pencong geothermal area. Total magnetic field data obtained using Procession Proton Magnetometer (PPM). The results show that the data processing geothermal area in in Pencong Gowa South Sulawasi value with the magnetic anomalies ranging to $-1600 \mathrm{nT}$ up to $1800 \mathrm{nT}$ and show that the area there is a fracture (break). In addition it was found that in the area of geothermal Pencong there are 3 layering of rock that is clay cap (clays and tuff) as a hot water discharge, reservoir zone consists of rock breccia, basalt rock weathered or shale (flake) is suspected as a rock fluid heated by rocks heating, heat source consists of basalt and andesite rocks altered.
\end{abstract}

Keywords : Magnetic Methods, Geothermal, Magnetic Anomaly, Subsurface Structures.

\section{PENDAHULUAN}

Posisi Indonesia yang terletak pada pertemuan tiga lempeng (Eurasia, Hindia, Australia, dan Pasifik) menyebabkan terbentuknya deretan gunungapi di sebagian wilayah negara ini, dan menyebabkan terbentuknya sumber energi panasbumi di sekitar gunungapi tersebut. Salah satu prospek panas bumi di Indonesia khususnya Sulawesi selatan adalah di daerah Pencong, Kecamatan Biringbulu Kabupaten Gowa. Manifestasi panas bumi tersebut ditandai dengan adanya beberapa titik sumur mata air panas, daerah ini menunjukkan kenampakan panas bumi ke permukaan dengan temperatur mencapai $\pm 50^{\circ} \mathrm{C}, \mathrm{pH}$ netral dan alterasi batuan breksi dan tufa, komponen batuannya sebagian besar berkomposisi basal dan berkomposisi andesit. Menurut Dinas Energi dan Sumber Mineral Makassar, berdasarkan keadaan bentang alamnya Kabupaten Gowa dibedakan atas 4 satuan morfologi, yakni: 1) Satuan morfologi pegunungan mempunyai sifat-sifat relief topografi yang tinggi, tekstur topografi kasar, batuan penyusunnya didominasi oleh batuan gunung api Lompobattang, menyebar disekitar gunung Bawakaraeng, 2) Satuan morfologi perbukitan mempunyai sifat-sifat relief topografi dan tekstur sedang, batuan penyusunnya terdiri dari batuan gunung api batu rappe-cindako dan batuan beku serta batuan formasi camba, menyebar di daerah sekitar perbukitan Sapaya dan Tombolo serta 
Erelembang, 3) Satuan morfologi bergelombang mempunyai sifat-sifat relief topografi rendah sampai sedang, tekstur topografi halus sampai sedang, batuan penyusunnya terdiri dari batuan formasi camba dan batuan gunung api batu rappe-cindako serta batuan beku, menyebar di daerah sekitar Parangloe dan Bontomarannu, 4) Satuan morfologi pedataran, mempunyai sifatsifat relief topografi sangat rendah dengan tekstur topografi halus, batuan penyusunnya didominasi oleh endapan aluvium.

Ada beberapa metode geofisika yang digunakan dalam menentukan struktur bawah permukaan suatu daerah panas bumi yakni metode gravity atau metode gaya berat, metode seismik, dan metode magnetik. Telah banyak peneliti sebelumnya yang menggunakan metodemetode tersebut seperti Winda Ramadhani (2014) yang menggunakan metode gaya berat mengidentifikasi struktur bawah permukaan Desa Sumbermanjingwetan dan Desa DrujuMalang Selatan, begitu juga dengan Saiful Nurul Hudha,dkk (2014) yang menggunakan metode seismik refraksi di lapangan panas bumi diwak dan derekan, Kecamatan Bergas, Kabupaten Semarang.

Beberapa metode geofisika yang digunakan dalam mengidentifikasi struktur bawah permukaan memiliki kelebihan dan kekurangangannya masing-masing. Namun untuk daerah panas bumi metode magnetik lebih banyak digunakan karena selain proses akuisisi data yang tidak terlalu rumit dibandingkan metode grafity dan seismik, metode ini sangat sensitive terhadap perubahan vertical, umumnya digunakan untuk mempelajari tubuh intrusi, batuan dasar, urat hidrotermal yang kaya akan mineral ferromagnetik, struktur geologi. Selain itu mudah mengidentifikasi mineral-mineral yang mendekati temperature curie oleh karena itu efektif digunakan untuk mempelajari daerah yang dicurigai mempunyai potensi geothermal.
Boko Nurdianto S (2004), Fristy Lita (2012), dan Sigit Darmawan (2012), ketiga peneliti tersebut telah berhasil menunjukkan struktur bawah permukaan dengan metode magnetik berupa batuan-batuan penyusun daerah panas bumi yang mengontrol manifestasi air panas di Lereng Utara Gunungapi Ungaran (Boko N S, 2004), Gunung Arjuna- Welirang Malang (Fristy Lita, 2012), dan Bledug Kuwu Groboga Semarang (Sigit Darmawan, 2012) mengakuisisi data anomali magnetik yang diperoleh dengan menggunakan Proton Processing Magnetometer.

Berdasarkan latar belakang yang telah disebutkan diatas maka peneliti bermaksud untuk mengetahui karakteristik sebaran anomali magnetik dan struktur bawah permukaan area panas bumi Pencong Kabupaten Gowa dengan menggunakan metode magnetik.

\section{METODE}

Jenis penelitian yang dilakukan adalah survey regional, yaitu melakukan pengukuran langsung di lapangan yang bertujuan memprediksi struktur bawah permukaan area panas bumi di Desa Pencong Kecamatan Biringbulu Kabupaten Gowa, secara geografis terletak pada 05 $30^{\prime} 17.4^{\prime \prime} \mathrm{LS}$ dan $119^{\circ} 44^{\prime} 23.8^{\prime \prime} \mathrm{BT}$

Prosedur yang dilakukan dalam penelitian ini adalah:

1. Proses Pengambilan Data.

Observasi dan pengambilan data magnetik dilaksanakan di wilayah permandian air panas Pencong yang terletak di Desa Pencong Kecamatan Biringbulu Kabupaten Gowa. Dengan menggunakan alat Proton Magnetometer tipe Geotron G5, Global Position System (GPS). Proses akusisi data dilakukan di daerah survei yang terdiri atas enam lintasan dimana pada setiap lintasan dibagi beberapa stasiun. Lintasan pertama sebanyak 33 titik, lintasan kedua 35 
titik, lintasan ketiga 30 titik, lintasan keempat 33 titik, lintasan kelima 32 titik dan lintasan keenam sebanyak 29 titik pengambilan data. Sedangkan pada Base dilakukan pengambilan data sebanyak 5 kali.

2. Proses Analisis Data

a. Melakukan koreksi harian dan koreksi IGRF pada data medan magnet.

Proses akuisisi data dimulai dengan melakukan koreksi harian dan koreksi IGRF terhadap data medan magnet yang didapatkan. Koreksi IGRF digunakan untuk menghilangkan pengaruh medan magnet dari dalam bumi yang disebabkan oleh medan magnet utama (Out Core) serta medan magnet dari kerak bumi. Seangkan koreksi harian berfungsi untuk menghilangkan pengaruh medan magnetik yang berasal dari luar bumi seperti pengaruh atmosfir (ionosfer).

Selain iu dilakukan juga koreksi drift yang berfungsi sebagai faktor koreksi data base. Tujuan dilakukannya koreksi ini untuk melihat perubahan nilai intensitas magnetik di base station yang bergantung pada waktu.

$T_{d c}=T_{o b s}-\frac{T_{B a s e 2}-T_{\text {Base } 1}}{t_{\text {Base } 2}-t_{\text {Base } 1}} X\left(t_{o b s}-t_{\text {Base } 1}\right)$

Keterangan :

T_dc = Nilai koreksi drift terhadap base

T_obs = Nilai medan magnet terukur dilapangan

T_Base2 = Nilai medan magnet akhir terukur tiap station

T_Base1 = Nilai medan magnet awal terukur tiap station

t_Base2 = Waktu pengukuran akhir tiap station

t_Base1 = Waktu pengukuran awal tiap station

t_obs = Waktu pengukuran medan magnet di base station

Setelah melalui proses koreksi IGRF (untuk permandian air panas Pencong, Gowa 43175,2
nT) dan koreksi harian, maka akan didapatkan nilai anomali magnetik total lapangan yang merupakan nilai magnetik kerak bumi.

$$
\Delta T=\left(T_{o b s}-T_{I G R F}-T_{V H}\right) \pm T_{d c}
$$

Keterangan :

$\Delta \mathrm{T} \quad=$ Anomali magnetik total

T_obs = Nilai medan magnet terukur di lapangan

$\mathrm{T}$ _IGRF $=$ Nilai medan magnet utama menurut isodinamik

T_VH = Nilai variasi harian (diurnal varition)

$\mathrm{T} \_\mathrm{dc}=$ Nilai koreksi drift terhadap base.

Setelah proses pengolahan data selesai dilakukan, maka hasil akhir adalah mencari nilai anomali magnetik yang kemudian akan di plot untuk melihat hasil dari anomali magnetik tesebut. Plot dilakukan dengan menggunakan program/software SURFER. Teknisnya hanya tinggal melakukan grinding dimana data di input merupakan koordinat titik ( $\mathrm{X}$ dan $\mathrm{Y}$ ) serta data anomali magnetinya. Sedangkan untuk pemodelan struktur bawah permukaan area penelitian dilakukan dengan membuat model menggunakan software Mag2dc. Parameter yang didapatkan yakni nilai suseptibilitas batuan berdasarkan nilai anomali magnetic area panas bumi Pencong, Gowa.

\section{HASIL DAN DISKUSI}

\section{Medan Magnet Total}

Topografi daerah penelitian dapat dilihat pada gambar 1 .

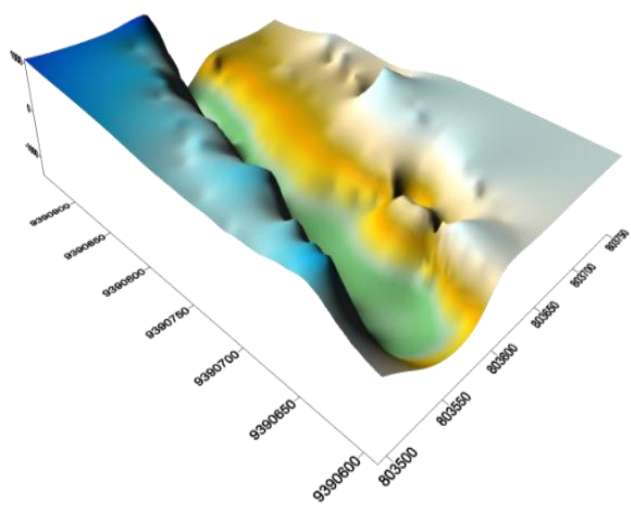


Gambar 1. Topografi daerah panas bumi pencong

Gambar 1 diatas menunjukkan peta topografi daerah penelitian. Terlihat bahwa permukaan daerah tersebut tidak rata, terdapat lereng dengan kemiringan mencapai $\pm 45^{\circ}$ (ESDM,2015). Daerah tertinggi untuk pengambilan data magnetik adalah $391 \mathrm{mdpl}$.

Peta medan magnet total yang didapatkan dalam pengukuran di air panas Pencong dapat dilihat pada gambar 2 .

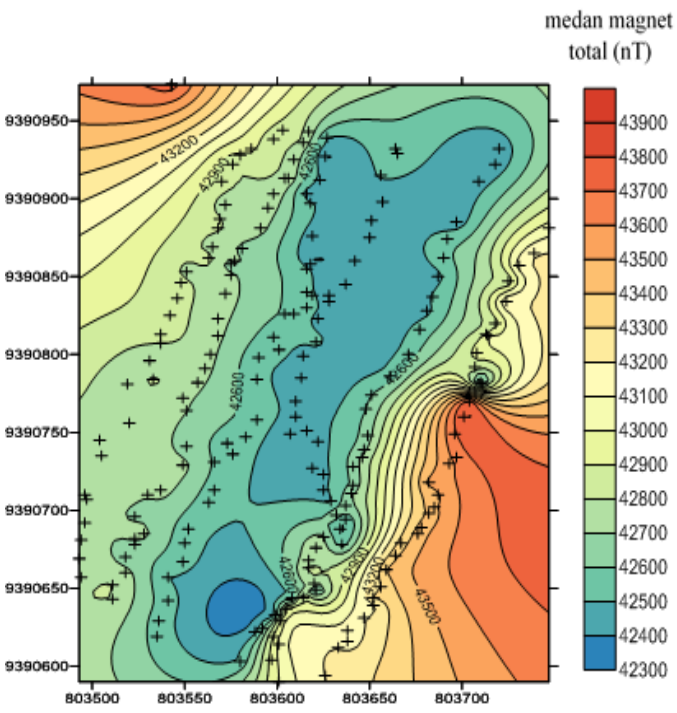

Gambar 2. Peta medan magnet total daerah panas bumi Pencong

Gambar 2 menunjukkan titik grid pengambilan data dan besar medan magnet total yang berada pada daerah pengukuran air panas Pencong

\section{Hasil Interpretasi Karakteristik Sebaran Anomali Magnetik}

Anomali medan magnet total diperoleh dengan melakukan beberapa koreksi pada data hasil pengukuran di lapangan, yaitu koreksi IGRF dan koreksi variasi harian. Pada peta anomali medan magnet total (gambar 3) terdapat klosur positif dan klosur negatif, hal ini menunjukkan bahwa anomali magnet adalah bersifat dipole (dwi kutub). Anomali medan magnet total sudah tidak begitu dipengaruhi oleh anomali lokal, hal ini terlihat pada sedikitnya jumlah dipole magnetik pada peta kontur.

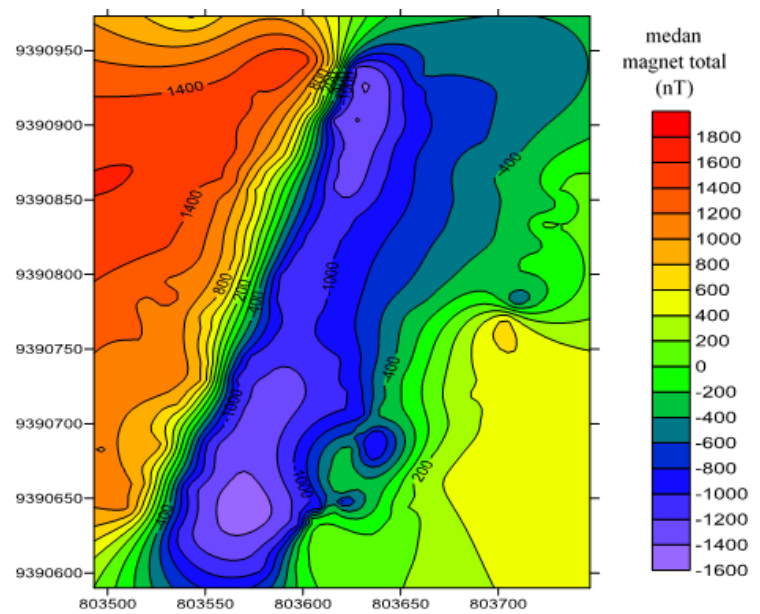

Gambar 3. Peta anomali medan magnet daerah panas bumi Pencong

Gambar 3 juga menunjukkan perbedaan intensitas magnetik yang cukup kuat ditandai dengan nilai anomali negatif dan positif yang tidak jauh berbeda dari -1600 nT sampai dengan +1800 nT. Setelah harga anomali total didapatkan maka selanjutnya adalah melakukan langkah berikutnya yakni, continuasi (pengangkatan). Pada penelitian ini digunakan upward continuation atau pengangkatan ke atas sejauh 50 meter untuk memisahkan antara anomali lokal dan anomali regional sehingga dapat dipisahkan antara batuan penyebab anomali pada posisi yang lebih dalam dengan yang lebih dangkal pada suatu kedalaman tertentu di bawah permukaan daerah pengukuran. Setelah di upward setinggi 50 meter, nilai anomalinya berkurang cukup jauh karena anomali magnetiknya telah di dominankan dikisaran -1600 nT sampai 1200 nT yang sebelumnya berada dikisaran -1600 nT sampai $1800 \mathrm{nT}$. 


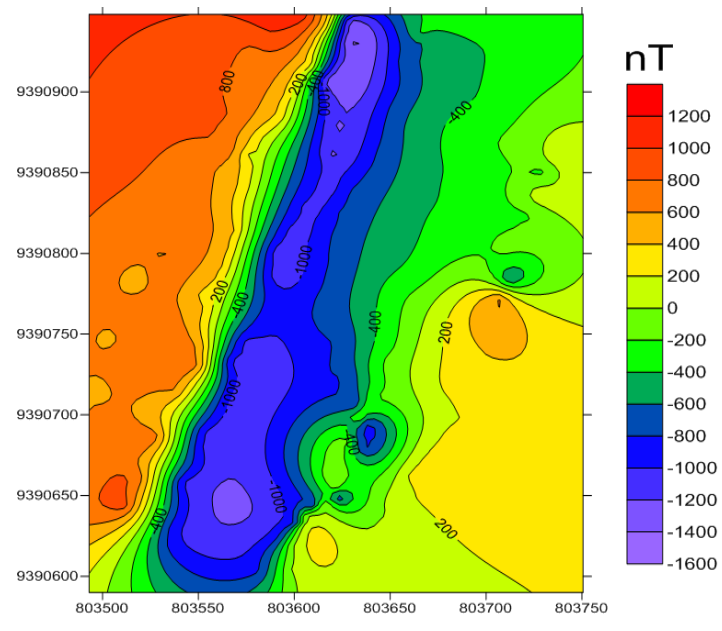

Gambar 4. Peta kontur upward continuation magnetik 50 meter

Nilai anomali tersebut menunjukkan kerentangan sifat magnetik batuan dan mineral berdasarkan tabel sifat kemagnetan batuan yakni anomali magnetik yang bernilai -1600 nT sampai dengan -200 nT dapat dikatakan medan magnet rendah atau disebut diamagnetik, karena berkaitan dengan batuan yang bersifat non magnetik seperti batuan sedimen dan batuan metamorf. Pada gambar 4 juga terlihat harga anomali sedang yang mulai dari 200 nT sampai dengan 800 nT ini biasa disebut paramagnetik, munculnya nilai anomali ini diduga karena adanya batuan beku yang telah mengalami pelapukan tingkat sedang sampai tinggi, sedangkan untuk anomali magnetik yang memiliki nilai mulai dari 1000 nT sampai dengan 1800 nT terlihat jelas bahwa mempunyai medan magnetik yang sangat tinggi atau biasa disebut ferromagnetik, hal ini diduga daerah tersebut didominasi oleh batuan beku yang telah mengalami proses mineralisasi yang diakibatkan oleh proses magmatik ataupun proses yang lainnya (Salahuddin H. 2010).

Pada peta kontur yang ditunjukkan gambar 2, 3, dan 4 dapat dilihat pula bahwa terdapat perbedaan garis kontur, dimana berdasarkan jaraknya ada garis kontur yang lebih rapat dan ada pula yang jarang. Hal ini menunjukkan bahwa daerah penelitian dengan garis kontur rapat terdapat lembah yang cukup curam sedangkan yang jarang terdapat lembah yang dangkal. Dalam hal ini dapat pula dilihat pada peta topografi yang menunjukkan adanya lembah tersebut yang mencapai kemiringan $\pm 45^{\circ}$.

\section{Pemodelan Struktur Bawah Permukaan} Daerah Anomali Magnetik.

Peta kontur pada gambar 5 menunjukkan daerah penelitian yang dimodelkan struktur bawah permukaannya. Daerah tersebut dipilih karena diduga daerah tersebut merupakan dip angel dari sikuen perlapisan batuan.

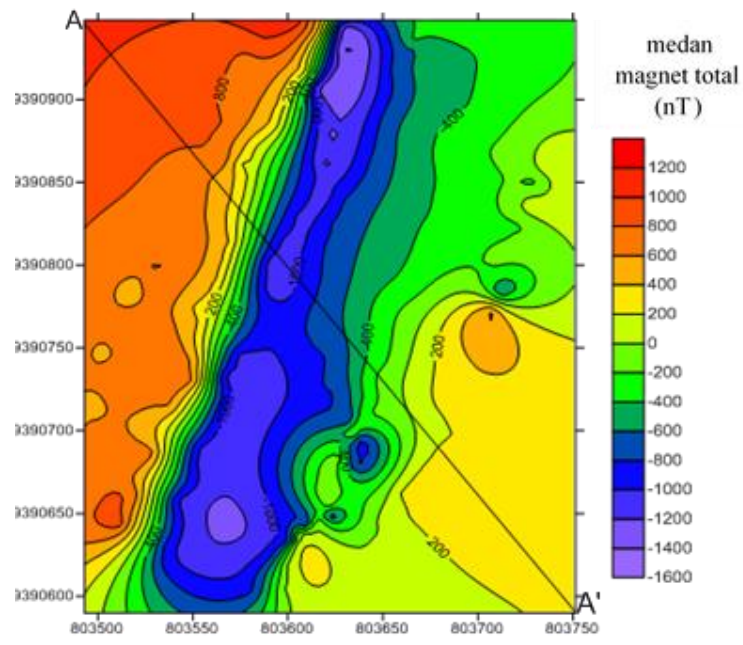

Gambar 5. Peta kontur yang telah di slice pada upward continuation magnetik 50 meter

Intepretasi struktur bawah permukaan daerah anomali magnetik dilakukan dengan menggunakan software geomagnet Mag2DC. Adapun parameter- parameter yang digunakan atau diinput untuk menampilkan kurva intepretasi ialah nilai IGRF sebesar $43175.2 \mathrm{nT}$, sudut inklinasi sebesar $1.0461^{\circ}$ dan sudut deklinasi sebesar $-27.2085^{\circ}$ daerah penelitian, serta besar nilai anomali magnetiknya (hasil slice), station spacing 10 .

Gambar 6 dan 7 diatas terlihat bahwa pada lintasan terjadi fenomena naik turunnya nilai anomali magnetik, sehingga menghasilkan dua buah puncak positif dan satu puncak negatif. Hal ini diduga karena adanya terdapat patahan atau terobosan akibat pemanasan terus-menerus. Pada gambar 6 menunjukkan model penampang 
magnetik batuan yang ada pada daerah lintasan A-A' memperlihatkan body anomali magnetik dan jenis batuan diantaranya, shale atau serpihan, basal lapuk, basal, breksi dan andesit terubah. Sedangkan untuk gambar 7 memperlihatkan struktur lapisan bawah permukaan pada lintasan A-A' yaitu daerah hot rock, hot rock terubah, reservoir, dan clay cap.

Anomali magnet pada lintasan A memperlihatkan harga antara $\hat{\mathrm{A}}-705 \mathrm{nT}$ s/d 716.0 nT. Terjadi penurunan nilai anomali yang cukup tajam yaitu dari A 25.5 ke A 35.5 diduga penurunan nilai anomali itu terjadi akibat adanya kontak geologi batuan yang juga menandakan adanya lapisan reservoir disekitar titik itu. Lintasan A-A' ini didominasi oleh batuan piroklastik pada batuan penutupnya. Anomali yang muncul pada kontur yang terlihat pada lintasan A-A' diduga adalah batuan beku yang merupakan hasil intrusi dari rekahan magma Gunungapi Lompobattang. Hal ini sesuai dengan kondisi statigrafi daerah tersebut dimana daerah penelitian termasuk kelompok satuan batuan breksi dan tufa batuan Gunungapi Lompobattang.

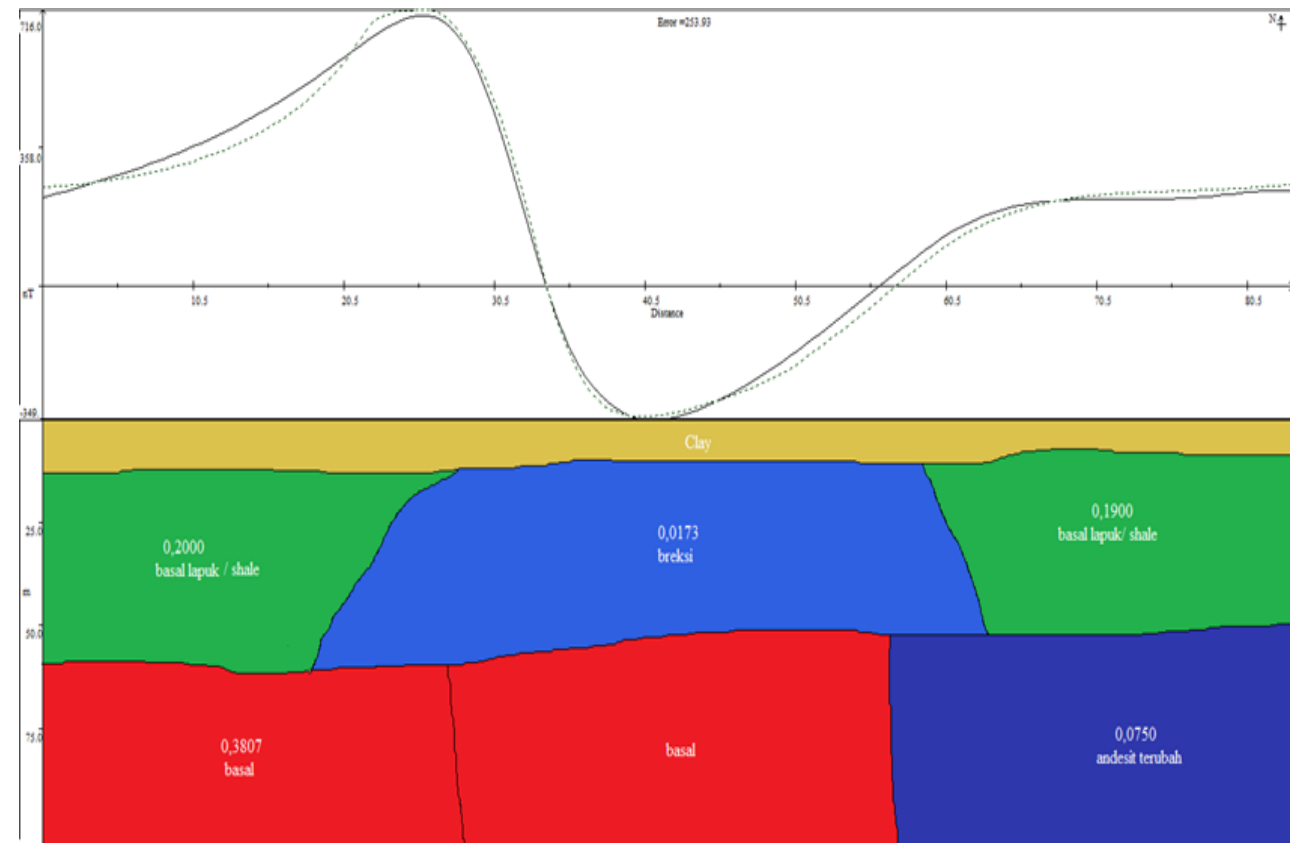

Gambar 6. Model penampang magnetik batuan pada lintasan A-A' 


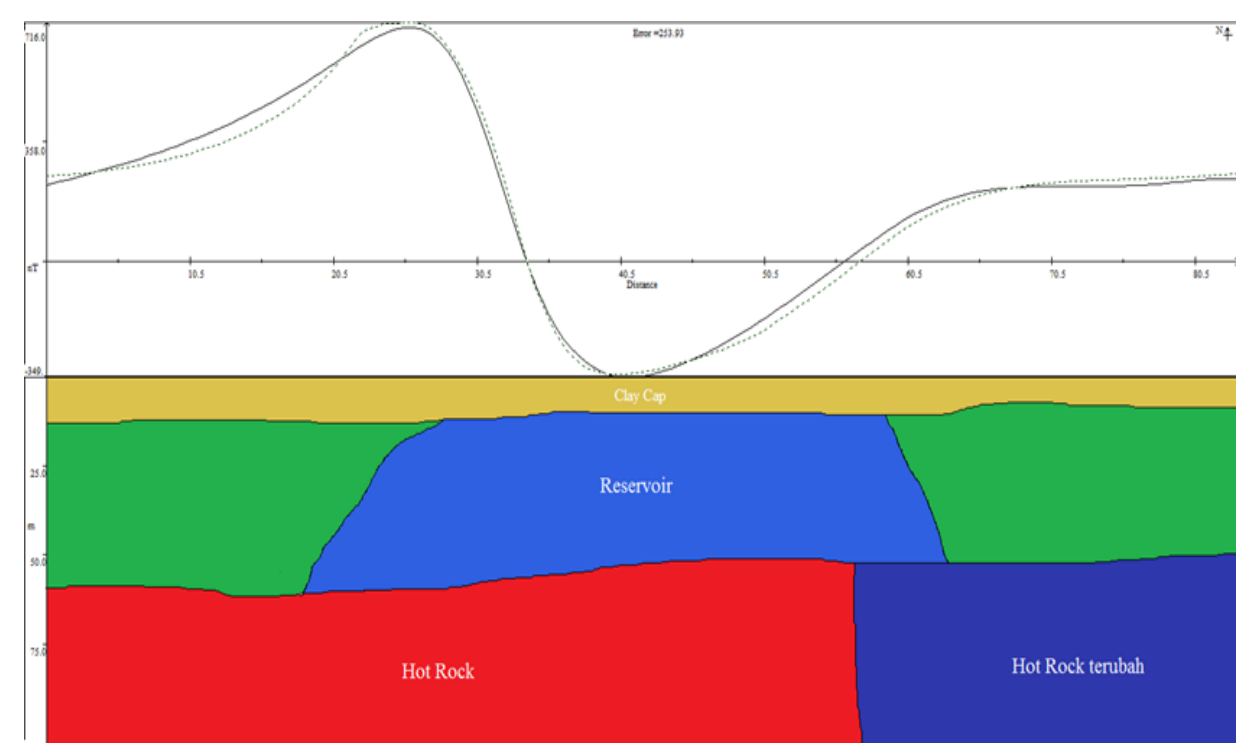

Gambar 7. Pendugaan struktur lapisan bawah permukaan pada lintasan A-A',

Hasil intepretasi lintasan A-A' dengan menggunakan Mag2dc, terlihat dengan jelas harga suseptibilitas dari hasil pemodelan body anomali magnetik yang ada dibawah permukaan. Pada lintasan A-A' kontras suseptibilitas magnetik cenderung bervariasi pada tiap-tiap lapisannya. Lapisan paling atas merupakan daerah lapisan overburden (penutup pada reservoir fluida panas bumi ).

Lapisan ini menurut data hasil penelitian Hadriani (2016) ditempat penelitian yang sama dengan menganalisa kandungan mineral sampel-sampel tanah dan batuan yang diambil dengan menggunakan SEM-EDS (Scanning Electron Microscopy-Electron Dispersive Spectroscopy) dan XRD (X-Ray Diffraction) merupakan batuan piroklastik. Dimana diketahui bahwa mineral disana sebagian besar mengandung mineral $\mathrm{SiO}_{2}$ (kuarsa), $\mathrm{Al}_{2} \mathrm{O}_{3}$, $\mathrm{FeO}, \mathrm{MgO}$, dan $\mathrm{CaO}$ yang pada umumnya ditemukan dalam komposisi batuan piroklastik seperti lempung dan tufa.

Lapisan kedua terdiri dari body yang memiliki nilai suseptibilitas $(\mathrm{k})=0.200 \times 10^{3}$, $0.0173 \times 10^{3}$, dan $0.1900 \times 10^{3}$, pada kedalaman 10 sampai dengan 55 meter di atas permukaan laut (mdpl). Lapisan body ini diidentifikasikan sebagai jenis batuan Gunungapi Lompobattang kuarter Pleistocene, dari nilai suseptibilitasnya batuan tersebut dapat diklasifikasikan dengan jenis batuan sedimen vulkanik aliran piroklastik yaitu breksi dan basalt lapuk atau shale.

Lapisan ketiga terdiri dari body yang memiliki nilai suseptibilitas $(\mathrm{k})=0,3807 \times 10^{3}$ dan $0.0750 \times 10^{3}$ pada kedalaman 55 sampai dengan $\pm 80 \mathrm{mdpl}$. Lapisan ini berdasarkan dari nilai suseptibiltasnya diidentifikasikan sebagai jenis batuan beku yaitu basal dan andesit terubah (Telford, 1990). Berdasarkan hasil identifikasi maka dapat diketahui bahwa struktur bawah permukaan daerah panas bumi Desa Pencong terdiri dari 3 lapisan yaitu lapisan clay cap yang merupakan lapisan pertama yang menjadi lapisan penutup, lapisan reservoir yang merupakan lapisan dengan formasi batuan yang mampu menyimpan dan mengalirkan uap ataupun air panas, dan lapisan ketiga merupakan lapisan heat source atau lapisan yang menjadi sumber panas.

Pada lapisan heat source tersebut terdapat batuan andesit terubah yang diduga awalnya merupakan intrusi basal yang masih terpanaskan atau terjadi ubahan hidrotermal 
sehingga mengalami proses alterasi karena terpanaskan oleh magma yang terletak dibawahnya. Dari proses alterasi itu kemudian memunculkan indikasi terjadinya proses demagnetisasi pada batuan basal yang sudah teralterasi oleh magma yang merupakan sumber panas menjadi batuan andesit terubah.

\section{SIMPULAN}

Berdasarkan hasil pembahasan baik secara kualitatif maupun kuantitatif yang telah diuraikan di atas dapat disimpulkan bahwa area panas bumi daerah Desa Pencong Kabupaten Gowa Sulawasi Selatan mempunyai karakteristik -1600 nT sampai dengan -200 nT dapat dikatakan medan magnet rendah atau disebut diamagnetik, harga anomali sedang yang mulai dari $200 \mathrm{nT}$ sampai dengan $800 \mathrm{nT}$ ini biasa disebut paramagnetik, munculnya sedangkan untuk anomali magnetik yang memiliki nilai mulai dari $1000 \mathrm{nT}$ sampai dengan $1800 \mathrm{nT}$ terlihat jelas bahwa mempunyai medan magnetik yang sangat tinggi atau biasa disebut ferromagnetik. Hasil pemodelan penampang lintasan A-A' menggunakan Mag2dc menunjukkan bahwa terdapat patahan atau terobosan akibat pemanasan, dan terdapat 3 perlapisan batuan di air panas Pencong yaitu clay cap (lempung dan tuff) sebagai tempat keluarnya air panas, zona reservoir terdiri dari batuan breksi, batuan basal lapuk atau shale (serpihan) diduga sebagai batuan fluida yang terpanaskan oleh batuan pemanas, heat source terdiri dari batuan basal dan batuan andesit terubah.

\section{DAFTAR RUJUKAN}

Darmawan, S., Danusaputro, H., Yulianto, T. (2012). Interpretasi Data Anomali Medan Magnetik Total Untuk Permodelan Struktur Bawah Permukaan Daerah Manifestasi Mud
Vulcano (Studi Kasus Bledug Kuwu Grobogan). Jurnal Geofisika, Vol. 13, No. 1,14 .

DESDM. (2015). Laporan Penyelidikan Geologi Terpadu Desa Pencong Gowa Provinsi Sulawesi Selatan. Makassar: Bidang Geologi Sumber Daya Mineral Kantor Wilayah Departemen Pertambangan dan Energi Provinsi Sulawesi Selatan.

Gupta, H. dan Ray, S. (2007). An Outline of the Geology of Indonesia, IAGA.Jakarta

IAGA Working Group V-8. (1995). International Geomagnetic Reference Field, 1995 revision. Submitted to EOS Trans. Am. Geophys. Un. Geophysics, Geophys. J. Int., J. Geomag. Geoelectr.,Phys. EarthPlanet.Int., and others.

Kasbani. (2009). Tipe Sistem Panas Bumi Indonesia dan Estimasi Potensi Energinya. Prosiding Hasil Kegiatan Kelompok Penelitian Panas Bumi PMG Badan Geologi.

Lita, F. (2012). Identifikasi Anomali Magnetik Di Daerah Prospek Panas Bumi Arjuna - Welirang. In Skripsi . Depok : FMIPA UI.

Mustang, A. D. (2007). Penyelidikan Gaya Berat dan Geomagnet di Daerah Panas Bumi Bonjol, Kabupaten Pasaman Provinsi Sumatera Barat. Bandung: Pusat Sumber Daya Geologi.

Nurdianto, B., Wahyudi., Suyanto,Imam. (2004). Analisis Data Magnetik Untuk Mengetahui Struktur Bawah Permukaan Daerah Manifestasi Air Panas Di Lereng Utara Gunungapi Ungaran. Prosiding Himpunan Ahli Geofisika Indonesia, 
92 Jurnal Sains dan Pendidikan Fisika. Jilid 14, Nomor 3, Desember 2018, hal. 84 - 92

YogyakartaArdianto, Randy. 2009.

Analisa Dampak Madden Julian

Oscillation Terhadap Curah Hujan Di

Pontianak. Akademi Meteorologi Dan

Geofisika, Jurusan Meteorologi.

Tangerang.

Husein, Salahudin. (2010). Geologi Dasar.

Jurusan Teknik Geologi Fakultas

Teknik Universitas Gadah

Mada.Yogyakarta
Telford, L. G. (1990). Applied Geophysics. New York: Cambridge.

U.S. Geological Survey Information Service. (2016). World IGRF Magnetic Chart, web page:www.ngdc.noaa.gov.

Ramadhani, W. (2014). Identifikasi Struktur Bawah Permukaan dengan Menggunakan Metode Gravity di Desa Sumbermanjingwetan dan Desa Druju - Malang Selatan. Malang : Universitas Brawijaya Malang. 